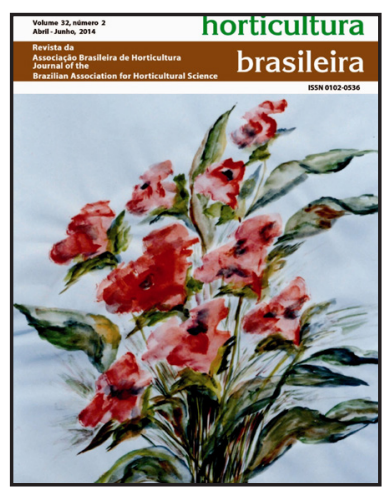

Foto: Recorte da obra "Primavera" de Ieli Carneiro. A imagem completa e a biografia da autora estão publicadas na terceira capa deste número.

\section{A produção de flores e a} agricultura familiar

A floricultura é uma atividade econômica importante dentro do agronegócio brasileiro. Segundo o Instituto Brasileiro de Floricultura (IBRAFLOR), desde 2006 o segmento se mostra vigoroso, exibindo taxas de crescimento da ordem de 8,0 a $15 \%$ em volume e de 15,0 a $17 \%$ em valor. Na comparação 2012/2013, o mercado cresceu $12 \%$ em faturamento e alcançou 5,2 bilhões de reais. Para 2014, estima-se crescimento na ordem de 8 a $10 \%$.

São cerca de 8 mil produtores cultivando flores e plantas verdes em vasos, flores de corte temperadas e tropicais, folhagens de corte e plantas para paisagismo. A atividade é intensiva em mão de obra e gera, de acordo com o mesmo instituto, cerca de oito empregos diretos por hectare. No Brasil são 206 mil empregos diretos em toda a cadeia produtiva, incluindo mão de obra familiar e contratada.

Por se tratar de atividade com grande capacidade de geração de renda, variando de 50 mil a 100 mil reais por hectare cultivado/ano, a floricultura é muito atrativa para pequenos agricultores. A área média nacional das propriedades envolvidas com flores e plantas ornamentais é de respectivamente 3,5 e 6,5 ha.

É importante ressaltar que a atividade demanda mão de obra intensiva e adoção de tecnologias avançadas na produção, pós-colheita e logística de distribuição e venda, principalmente para flores cortadas e em vasos. Nesse sentido, visando minimizar as dificuldades da atividade junto aos agricultores familiares e aproveitar as demandas e oportunidades regionais nos vários estados brasileiros, é que várias ações estão sendo realizadas junto aos produtores, principalmente pelas empresas oficiais de extensão rural dos estados, EMATER, e por instituições do Sistema $\mathrm{S}$, SEBRAE e SENAR.

O Ministério da Agricultura, Pecuária e Abastecimento (MAPA) também vem atuando na atividade junto à Camara Setorial de Flores e de Plantas Ornamentais. O Ministério do Desenvolvimento Agrário (MDA) ainda não despertou para as oportunidades da floricultura para seu público direto, não tendo ainda nenhuma ação concreta realizada.

A sustentabilidade do negócio da floricultura na agricultura familiar requer um conjunto de medidas que vão desde a ampliação do acesso dos produtores a insumos básicos e adoção de novas tecnologias de produção, até a capacitação dos técnicos da extensão rural, dos produtores e de suas famílias e dos trabalhadores rurais. É preciso também estimular e viabilizar pesquisas voltadas para tecnologias de produção que sejam mais adequadas às realidades da agricultura familiar, além da recomendação e/ ou desenvolvimento de novas cultivares ou de tecnologias de reprodução das espécies da nossa biodiversidade com potencial comercial. A pesquisa nacional em floricultura é ainda incipiente.

Material de comunicação e informação apropriado para os produtores rurais precisam ser disponibilizados. A comunicação entre os grupos de produtores para troca de informações não somente sobre tecnologias, mas também sobre mercado, formas de organização do setor, local e venda dos produtos, precisa ser propiciada. Criação de novos pontos de venda, feiras e eventos locais, regionais e nacionais de floricultura e a garantia de financiamento para os investimentos no setor também são necessárias.

A montagem e execução de programas municipais e estaduais para o desenvolvimento sustentável do setor poderá levar maior dinâmica ao processo de expansão da floricultura nacional, assim como projetos de propaganda que levem ao aumento do consumo.

A criação de associações locais e regionais de produtores e/ou cadeias produtivas deve ser fomentada. Essas associações podem organizar as demandas, facilitar a comercialização e mediar o acesso aos recursos governamentais disponíveis para a floricultura.

No Distrito Federal, o governo, valendo-se da elevada renda per capita e nível cultural dos habitantes, além das excelentes condições climáticas para produção de flores, fez da Floricultura uma de suas prioridades desde 2007. Brasília destaca-se como primeiro consumidor per capita de flores do país, com R $\$ 43,72$ comparados aos $\mathrm{R} \$ 26,00$ da média nacional, demanda coberta em apenas 20\% pela produção local.

Coube à Secretaria de Agricultura e Desenvolvimento Rural (SEAGRI) e à sua empresa vinculada, Emater-DF, a elaboração e execução de um programa para o desenvolvimento da floricultura local. A EMATER-DF promove ações de sensibilização no campo, capacitação de seus técnicos, dos trabalhadores e produtores, e missões técnicas, além de incentivar o associativismo e a comercialização. São 127 pequenos produtores assistidos, cultivando flores e plantas ornamentais em aproximadamente 545 hectares (EMATER-DF) e duas organizações de produtores rurais: uma associação (Central Flores) e mais recentemente, resultado desse novo programa, a cooperativa Multiflor.

A Multiflor se iniciou com 21 cooperados, 14 deles mulheres, esposas e ajudantes de seus maridos na produção de hortaliças, e desde então vem procurando ampliar tanto o número de cooperados, quanto o "mix" de seus produtos.

A Declaração de Aptidão ao PRONAF (DAP JURÍDICA) foi emitida à cooperativa três anos depois do início de suas atividades e conta hoje com 54 membros, sendo $78,7 \%$ agricultores familiares com DAP individual (Declaração esta emitida pelo MDA).

Em 2013, a Cooperativa Multiflor foi cadastrada como fornecedor das compras institucionais do Governo do DF e teve seu primeiro contrato com a Companhia Urbanizadora da Nova Capital do Brasil (NOVACAP) para fornecimento de plantas de forração para ajardinamento dos canteiros urbanos da cidade.

Colaboram ainda com o projeto da Floricultura no Distrito Federal, o Ministério da Integração Nacional por meio da SUDECO, a Fundação Banco do Brasil e o MAPA, além das emendas parlamentares distritais que têm destinado recursos para o Programa de Floricultura da EMATER-DF, permitindo assim a inclusão de todos os produtores locais no evento anual nacional de floricultura FEST FLOR BRASIL, idealizado pela empresa de extensão.

(Cleison Medas Duval, Engenheiro Agrônomo, Mestre em Fitopatologia - Extensionista Rural da EMATER-DF. cleison.emater@gmail. com)

As idéia aqui expressas e as informações apresentadas são de responsabilidade do autor. 